\title{
Material quantity estimation modelling of bridge sub- substructure using regression analysis
}

\author{
M Khazin Alhusni ${ }^{1 *}$, Andreas Triwiyono ${ }^{2}$, Inggar Septhia Irawati ${ }^{2}$ \\ ${ }^{1}$ Department of Public Works Sleman District, Yogyakarta, Indonesia \\ ${ }^{2}$ Department of Civil Engineering and Environment, Gadjah Mada University, Yogyakarta, Indonesia
}

\begin{abstract}
In construction field, a time completion and an adherence to budget are two factors that mainly influence the successful of the projects. The adherence to the budget can be achieved when the estimated budget is closed to the actual cost. For the owners, cost estimation is necessary as a guidance in determining the amount of investment. Therefore, it is very important to know the estimation of the project cost by using the limited data before the detailed plans and specifications of the project are identified. However, in the case of bridge substructure preliminary cost estimation, there is a lack information about material quantity estimation models due to the difficulties of soil characteristic and hydrological conditions. Hence, this research aims to develop the estimation of material quantity models of the abutment and caisson of bridge, with the Presetressed Concrete I-Girder (PCI Girder) superstructure located in Sleman district, Yogyakarta province, Indonesia. The database used for developing model was obtained by conducting sub-structure structural analysis of 15 abutments and 45 caissons. The bridges have a various span length, abutment height, and caisson depth. Material quantity estimation models were analysed by the multiple regression analysis methods. The span length and the abutment height are determined as independent variables to predict the concrete volume, the reinforcing steel weight, the caisson concrete volume, the cyclops concrete volume and the caisson reinforcing steel weight. This research proposed 11 equation models to estimate the concrete volume and reinforcing steel weight of abutment and caisson.
\end{abstract}

\section{Introduction}

In construction field, a time completion and an adherence to budget are two factors that mainly influence the successful of the projects (Fragkakis et.al, 2015). The adherence to the budget can be achieved when the estimated budget is closed to the actual cost. For the owners, cost estimation is necessary as a guidance in determining the amount of investment. Therefore, it is very important to know the estimation of the project cost by using the limited data before the detailed plans and specifications of the project are identified.

Several studies on the cost estimation at an early stage of the projects have been conducted. Initial cost estimation of bridge construction was developed by Muis (1995) for reinforced concrete, truss and composite bridge structure. The model was developed by applying several regression analysis. A study to develop a construction estimation cost model also performed by Lowe, et al. (2006) by developing a cost model estimation of the building construction by using regression analysis. Fragkakis, et al. (2010) conducted research on a cost estimate method for bridge superstructures using regression analysis and bootstrap. This study aims to develop the cost estimation model of the bridge superstructure of pre-stressed beams, box girders cast in place, and the balance cantilever box girder. Sulistyani (2014) conducted research on the model estimation of the volume and cost of patching on the pavement of provincial roads in Yogyakarta, Indonesia. Fragkakis, et al. (2015) conducted research on the preliminary cost estimation model for culvert. The study aims to develop the cost estimation model using the previous project information.

However, in the case of bridge substructure preliminary cost estimation, there is a lack information about material quantity estimation models due to the difficulties of soil characteristic and hydrological conditions, previous studies only focus to estimate the superstructure cost (Fragkakis et.al, 2011).

\footnotetext{
*Corresponding author: khazin.alhusni@gmail.com
} 
Hence, this research aims to develop the estimation of material quantity models of the abutment and caisson of bridge, with the Presetressed Concrete I-Girder (PCI Girder) superstructure located in Sleman district, Yogyakarta province, Indonesia. The model was figured out by applying the regression analysis.

'The regression analysis is one of the most widely used methods for parametric cost estimation at the early project stages. Traditionally, cost estimation is modelled by correlating the previous project data using regression analysis (Fragkakis et.al, 2010). However, the previous project data in Indonesia cannot be used for developing model because the newest version of Indonesian bridge loading standart (SNI 1725: 2016) was enacted on June 2, 2016 in Indonesia. Consequently, in this research, the bridge loading parameter in the design was be assigned based on this code.

\section{Research Method}

This research was conducted by dividing the procedure into two steps. First, the abutment and caisson structural design was conducted by considering various span length, abutment height and the caisson depth. Afterwards, regarding to the design results, the material quantity estimation models were developed by applying the multiple regression analysis.

The superstructure design was not conducted specifically. However, it was defined based on the product design spesification of Prefabricated Presetressed Concrete I-Girder (PCI Girder) that was produced by Wika Beton, one of Indonesian State-owned Enterprise. Refering to Wika Beton PCI Girder catalogue, the span lenght is restricted from $10 \mathrm{~m}$ up to $50 \mathrm{~m}$. The superstructure dimension of the bridge was defined for Aclass bridge category in accordence with Indonesian Department of Highway. Related to the category, the bridge has superstructure width of $9 \mathrm{~m}$. The superstructure cross section can be seen in Figure 1.

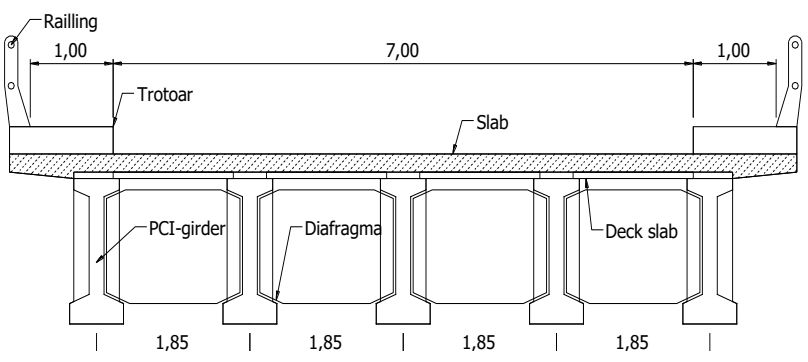

Fig.1. Bridge cross section

The bridge is located in area that is categorized in seismic zones 3 referred to Indonesian Earthquake Design Bridge Code SNI 2833-2008. The concrete compressive strength of the abutment and caisson was assumed of 20 $\mathrm{MPa}$. The yield strength of reinforced steel was assumed of $390 \mathrm{MPa}$. As previously describe, the bridge loading parameter used in the design was determined based on SNI 1725:2016 code. The typical form of bridge substructure, as presented in Figure 2

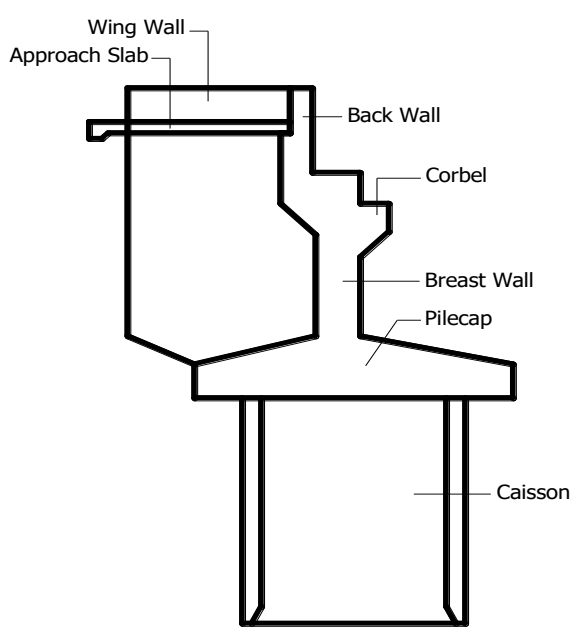

Fig.2. Typical form of abutment and caisson

\subsection{Soil characteristic}

The soil characteristic for structural analysis was determined as the 10 percentile from the 15 bridges soil investigation results located in Yogyakarta. The soil characteristic of 15 bridges can be seen in Table 1 .

Table 1. Soil characteristic

\begin{tabular}{|c|c|c|c|c|}
\hline \multirow[b]{2}{*}{ Bridge Name } & \multicolumn{2}{|c|}{$\begin{array}{c}\text { Subgrade } \\
\text { under pile cap }\end{array}$} & \multicolumn{2}{|c|}{$\begin{array}{l}\text { Subgrade under } \\
\text { the caisson }\end{array}$} \\
\hline & $\begin{array}{l}\text { Density } \\
(\mathrm{kN} / \mathrm{m} 3)\end{array}$ & $\begin{array}{c}\text { Internal } \\
\text { Friction } \\
\left({ }^{\circ}\right)\end{array}$ & $\begin{array}{l}\text { Density } \\
\left(\mathrm{kN} / \mathrm{m}^{3}\right)\end{array}$ & $\begin{array}{c}\text { Internal } \\
\text { Friction } \\
\left({ }^{\circ}\right)\end{array}$ \\
\hline $\begin{array}{l}\text { Gamping } \\
\text { Bridge }\end{array}$ & 19 & 37 & 19 & 37 \\
\hline $\begin{array}{c}\text { Grembyangan } \\
\text { Bridge }\end{array}$ & 19 & 36 & 19 & 36 \\
\hline $\begin{array}{l}\text { Wonosobo } \\
\text { Bridge }\end{array}$ & 18,3 & 35 & 18,3 & 35 \\
\hline $\begin{array}{l}\text { Rejodani } \\
\text { Bridge }\end{array}$ & 18,3 & 35 & 18,3 & 35 \\
\hline $\begin{array}{c}\text { Cebongan } \\
\text { Bridge }\end{array}$ & 19 & 37 & 19 & 37 \\
\hline $\begin{array}{l}\text { Temanggal } \\
\text { Bridge }\end{array}$ & 18,3 & 35 & 18,3 & 35 \\
\hline $\begin{array}{l}\text { Pereng } \\
\text { Bridge } \\
\end{array}$ & 17,3 & 34 & 17,3 & 34 \\
\hline $\begin{array}{c}\text { Kembang } \\
\text { Putih Bridge }\end{array}$ & 18,3 & 35 & 18,3 & 35 \\
\hline Merah Bridge & 18,3 & 35 & 18,3 & 35 \\
\hline Pojok Bridge & 18,3 & 36 & 18,3 & 36 \\
\hline Tapan Bridge & 18,3 & 35 & 18,3 & 35 \\
\hline $\begin{array}{c}\text { Kragilan } \\
\text { Bridge }\end{array}$ & 18,3 & 35 & 18,3 & 35 \\
\hline $\begin{array}{l}\text { Sambiroto } \\
\text { Bridge }\end{array}$ & 18,3 & 35 & 18,3 & 35 \\
\hline $\begin{array}{c}\text { Balerejo } \\
\text { Bridge } \\
\end{array}$ & 18 & 35 & 18 & 35 \\
\hline $\begin{array}{l}\text { Bedoyo } \\
\text { Bridge }\end{array}$ & 19,2 & 37 & 19,2 & 37 \\
\hline
\end{tabular}

Based on the 10 percentile calculation result of soil charactristic data, the density and the internal friction angle of subgrade at bottom of the caisson are $18 \mathrm{kN} / \mathrm{m} 3$ 
and $35^{\circ}$, respectivelly. The density and the internal friction angle of subgrade at the bottom of the pile cap are $18 \mathrm{kN} / \mathrm{m} 3$ and $35^{\circ}$, respectivelly.

It was assumed that the required cone penetration resistance was achieved in $4 \mathrm{~m}, 5 \mathrm{~m}$ and $6 \mathrm{~m}$ under the bottom surface of pile cap, as illutrated in Figure 2. As a result, there were three types of the caisson height, those were $4 \mathrm{~m}, 5 \mathrm{~m}$ and $6 \mathrm{~m}$.

\subsection{Database development}

The database was developed by designing the abutment and the caisson structure with various of bridges span length, the abutment height and the caisson depth. In the design for developing database, the bridges have five span lenght variations, i.e., $20 \mathrm{~m}, 25 \mathrm{~m}, 30 \mathrm{~m}, 35 \mathrm{~m}$, and $40 \mathrm{~m}$. The abutment height variations are $4 \mathrm{~m}, 6 \mathrm{~m}$, and $8 \mathrm{~m}$. The caisson depth variations are $4 \mathrm{~m}, 5 \mathrm{~m}$, and $6 \mathrm{~m}$. Hence, the number of data base obtained from the design results of abutment and caisson structure are 15 and 45, respectivelly. For each data, the volume of concrete and the weight of reinforcing steel are then applied to make the material estimation quantity model.

\subsection{Material quantity estimation model}

Material quantity estimation model was developed by taking into account the variables that considerable influence the dimensions of the structure and reinforcing requirements. Consequently, the span length $L$ and the abutment height $H$ were defined as independent variables, as illustrated in Figure 3. The volume of concrete at the abutment $V_{c}$, reinforcing steel weight of the abutment $V_{s}$, concrete volume of caisson $V_{c s}$, volume of cyclops concrete $V_{c c}$, and reinforcing steel weight of caisson $V_{s s}$ were defined as dependent variables.

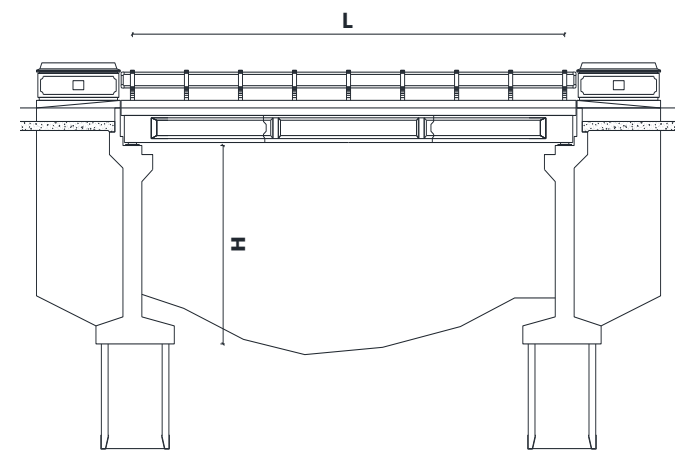

Fig.3. Longitudinal section of the bridge

\section{Results And Discussion}

\subsection{Design result}

In this paper, the design result of the abutment and caisson structure are represented by correlation chart between independent variables and dependent variables. The influence of bridge span $L$ towards the concrete volume
$V_{c}$ and the reinforcing steel weigh $V_{s}$ of the abutment can be seen in Figure 3 and Figure 4, respectivelly. Both figures typically showed that the greater bridge span dan abutment height, the more material quantity is required.

In the case of $4 \mathrm{~m}$ caisson depth, the effect of bridge span $L$ towards the concrete volume of caisson $V_{c s}$, the cyclops concrete volume $V_{c c}$ and the caisson reinforcing steel weight $V_{s s}$ can be seen in Figure 5, Figure 6 and Figure 7, respectivelly. In the case of $5 \mathrm{~m}$ caisson depth, the effect of bridge span $L$ towards the concrete volume of caisson $V_{c s}$, the cyclops concrete volume $V_{c c}$ and the caisson reinforcing steel weight $V_{s s}$ can be seen in Figure 8, Figure 9 and Figure 10, respectivelly. In the case of 6 m caisson depth, the effect of bridge span $L$ towards the concrete volume of caisson $V_{c s}$, the cyclops concrete volume $V_{c c}$ and the caisson reinforcing steel weight $V_{s s}$ can be seen in Figure 11, Figure 12 and Figure 13, respectivelly. Like the material quantity required on the abutment, the greater bridge span dan abutment height, the more material volume is required.

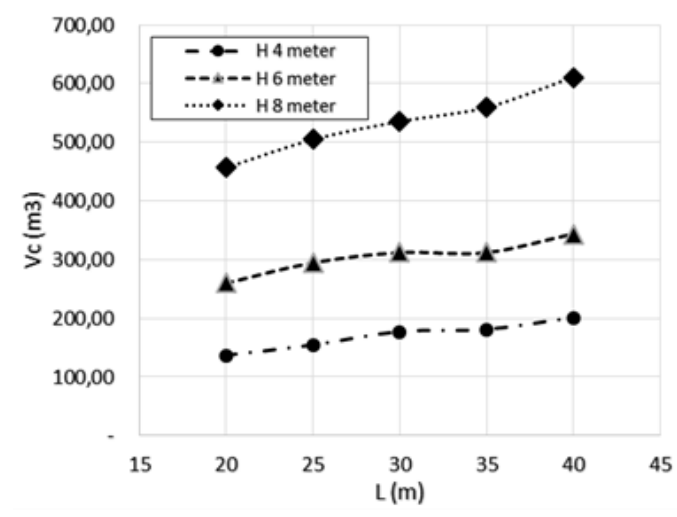

Fig.3. Correlation between bridge span and concrete volume of the abutment

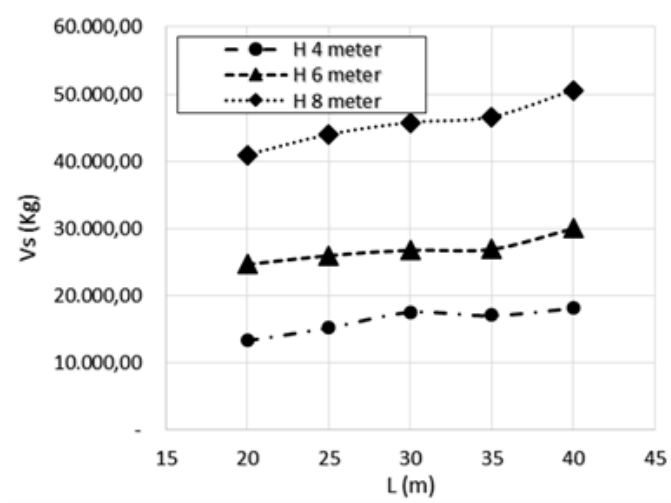

Fig.4. Correlation between bridge span and reinforcing steel weight of the abutment 


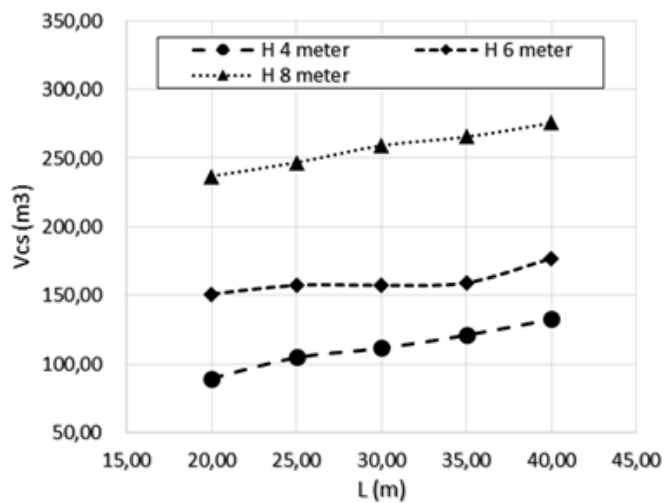

Fig.5. Correlation between concrete volume and span of the $4 \mathrm{~m}$ caisson

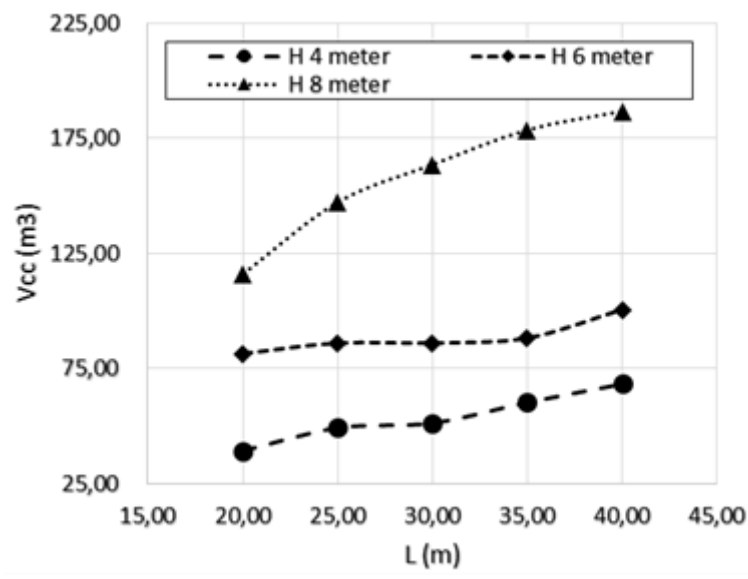

Fig.6. Correlation between cyclops concrete volume and span of the $4 \mathrm{~m}$ caisson

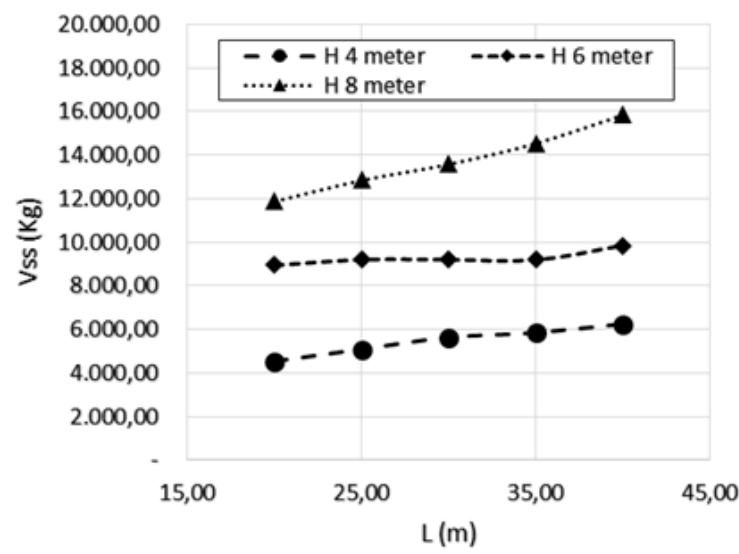

Fig.7. Correlation between reinforcing steel weight and span of the $4 \mathrm{~m}$ caisson

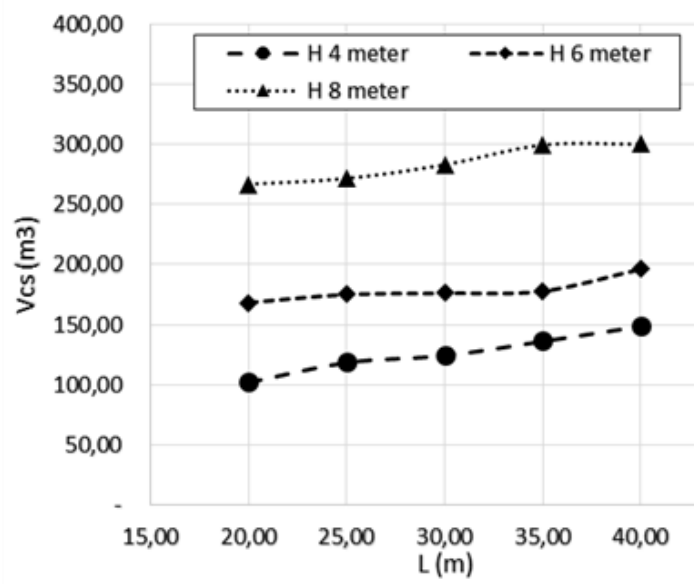

Fig.8. Correlation between concrete volume and span of the $5 \mathrm{~m}$ caisson

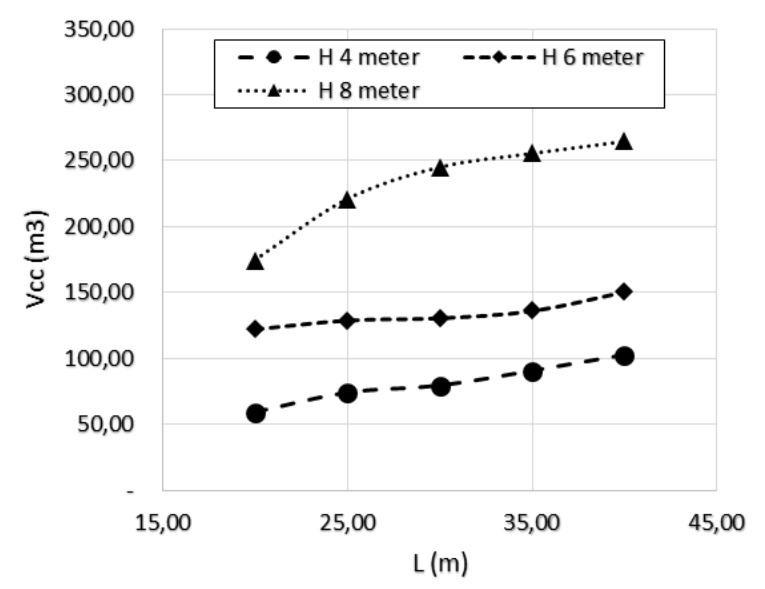

Fig.9. Correlation chart between cyclops concrete volume and span of the $5 \mathrm{~m}$ caisson

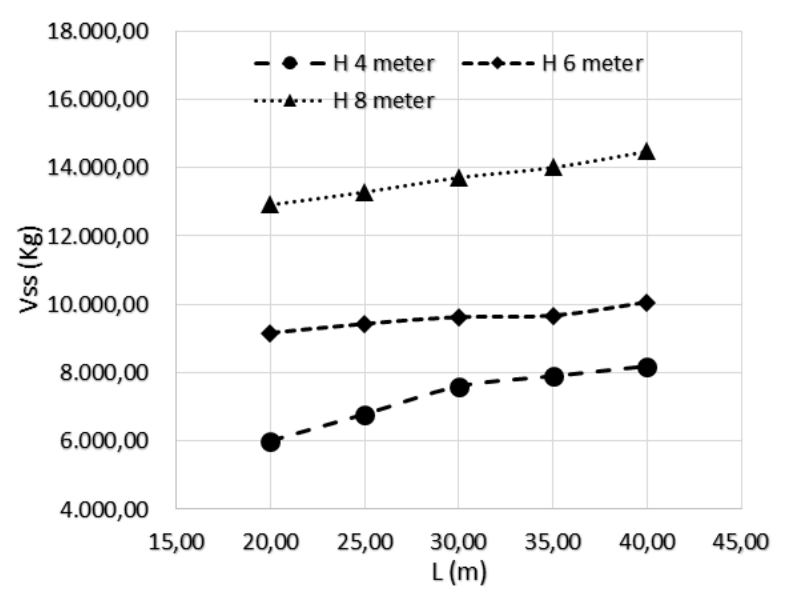

Fig.10. Correlation chart between reinforcing steel weight and span of the $5 \mathrm{~m}$ caisson 


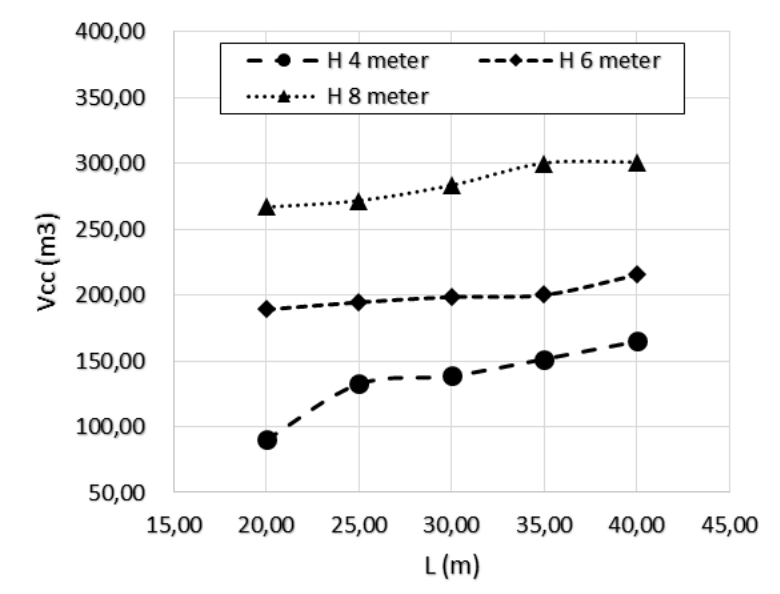

Fig.11. Correlation between concrete volume and span of the 6 $\mathrm{m}$ caisson

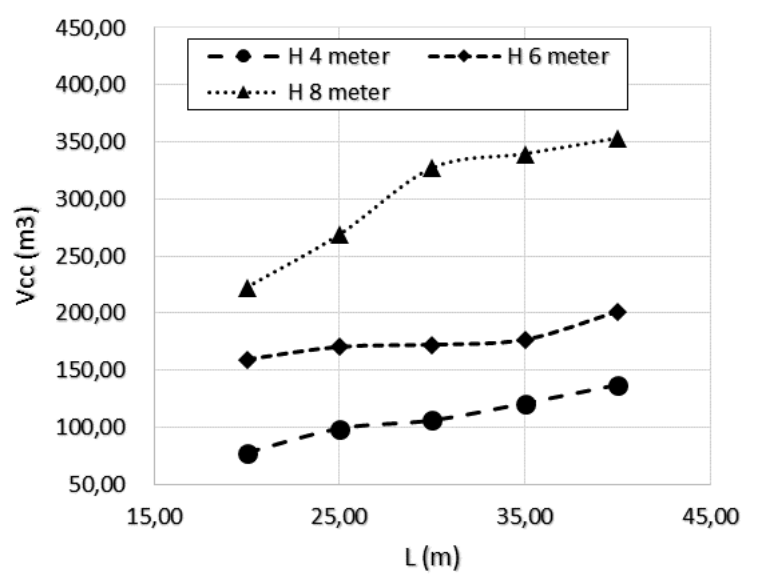

Fig.12. Correlation between cyclops concrete volume and span of the $6 \mathrm{~m}$ caisson

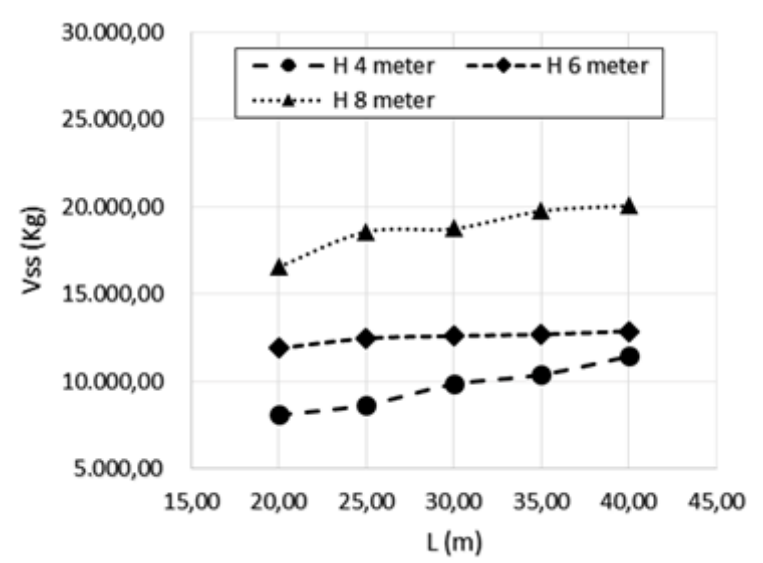

Fig.13. Relation between reinforcing steel weight and span of the 6 m caisson

\subsection{Statictical analysis}

\subsubsection{Multiple linear regression analysis}

In general, multiple regression analysis was applied to obtain the relation of material quantity to the bridge span, the height of abutment and the height of caisson base on material quantity obtained from design results. The relation of concrete volume $V_{c}$ and reinforcing steel weight $V_{s}$ to the bridge span $L$ and the abutment height $H$ can be seen in Equation 1 and 2, respectivelly.

$$
\begin{gathered}
V_{c}=-354,365+4,6 L+91,838 H \\
V_{s}=-22988,353+290,209 L+7311,548 H
\end{gathered}
$$

For the $4 \mathrm{~m}$ height caisson, the relation of concrete volume of the caisson $V_{c c}$, cyclops concrete volume $V_{c c}$ and reinforcing steel weight $V_{s s}$ to the bridge span $L$ and the abutment height $H$ can be seen in Equation 3, 4 and 5, respectivelly.

$$
\begin{gathered}
\mathrm{Vcs}=-91,23+1,693 \mathrm{~L}+36,159 \mathrm{H}(\mathrm{m} 3) \\
V_{c c}=-113,824+1,877 \mathrm{~L}+26,256 \mathrm{H} \\
V_{s s}=-2438,132+104,176 \mathrm{~L}+1576,658 \mathrm{H}
\end{gathered}
$$

For the $5 \mathrm{~m}$ height caisson, the relation of concrete volume of the caisson $V_{c c}$, cyclops concrete volume $V_{c c}$ and reinforcing steel weight $V_{s S}$ to the bridge span $L$ and the abutment height $H$ can be seen in Equation 6,7 and 8, respectivelly.

$$
\begin{gathered}
V_{c s}=-81,687+1,57 L+38,154 H \\
V_{c c}=-138,972+2,276 L+36,113 H \\
V_{s s}=-1668,902+75,651 L+1598,17 H
\end{gathered}
$$

For the $6 \mathrm{~m}$ height caisson, the relation of concrete volume of the caisson $V_{c c}$, cyclops concrete volume $V_{c c}$ and reinforcing steel weight $V_{s s}$ to the bridge span $L$ and the abutment height $H$ can be seen in Equation 9, 10 and 11 , respectivelly.

$$
\begin{gathered}
V_{c s}=-104,243+1,9456 L+43,449 H \\
V_{c c}=-208,735+3,755 L+48,551 H \\
V_{s s}=-2281,826+-51,57+1527,253 H
\end{gathered}
$$

\subsubsection{Normality test}

Normality test aims to determine whether or not the residuals variable of regression models have normal distribution. The $t$ test and $F$ test assumes that the residuals have a normal distribution. If this assumption is violated, the statistical test becomes invalid for a small number of samples. In this research, normality test data is conducted by using the Kolmogorov-Smirnov test. In this test, the data is normally distributed if the asymptotic significance value is greater than 0.05 . Normality test results as shown in Table 2. The results depict that the residuals data has normal distribution. 
Table 2. Normality test results

\begin{tabular}{|c|c|c|l|}
\hline \multirow{3}{*}{ Structure } & $\begin{array}{c}\text { Dependent } \\
\text { Variable }\end{array}$ & $\begin{array}{c}\text { Asymptotic } \\
\text { significance }\end{array}$ & Distribution \\
\hline \multirow{3}{*}{$4 \mathrm{~m}$ caissson } & $V_{c}$ & 0.20 & Normal \\
\cline { 2 - 4 } & $V_{s}$ & 0.20 & Normal \\
\cline { 2 - 4 } & $V_{c s}$ & 0.074 & Normal \\
\hline \multirow{3}{*}{$5 \mathrm{~m}$ caisson } & $V_{s s}$ & 0.20 & Normal \\
\cline { 2 - 4 } & $V_{c c}$ & 0.20 & Normal \\
\cline { 2 - 4 } & $V_{s s}$ & 0.20 & Normal \\
\hline \multirow{3}{*}{$6 \mathrm{~m}$ caisson } & $V_{c s}$ & 0.20 & Normal \\
\cline { 2 - 4 } & $V_{c c}$ & 0.20 & Normal \\
\cline { 2 - 4 } & $V_{s s}$ & 0.149 & Normal \\
\hline
\end{tabular}

\subsubsection{Multicollinearity test}

Multicollinearity test aims to determine whether the regression model found a correlation between independent variables. If independent variables in the regression models are strongly correlated each other, dependent variable resulted from the regression model is not reliable. The presence of multicollinearity can be determined by calculating the value of tolerance and the variance inflation factor (VIF). If the tolerance values are greater than 0.1 and VIF are less than 10 , it means that there are no multicollinearity problem. The multicollinearity test results between independent variables described in Equation 1 up to Equation 11 shows that both of tolerance values and VIF value are 1 . It can be determined that there are no multicollinearity problems in the regression models.

\subsubsection{Correlation analysis}

Correlation analysis was conducted to observe the correlation between dependent and independent variables. In this research, the multiple correlation analysis was applied. The multiple correlation analysis aims to determine the correlation direction and strength of two or more independent variables simultaneously towards a dependent variable. The result of multiple correlation analysis shows that both independent variables, that consist of the bridge span $\mathrm{L}$ and abutment height $\mathrm{H}$ expressed in Equation 1 to Equation 11, strongly influence the dependent variables with a correlation coefficient exceed 90\%, as shown in Table 3.
Table 3. Correlation test results

\begin{tabular}{|c|c|c|}
\hline \multirow{2}{*}{ Structure } & $\begin{array}{c}\text { Independent } \\
\text { Variable }\end{array}$ & $\begin{array}{c}\text { Correlation } \\
\text { Coefficient }\end{array}$ \\
\hline \multirow{3}{*}{ Abutment } & $V_{c}$ & 0.986 \\
\cline { 2 - 3 } & $V_{s}$ & 0.985 \\
\hline \multirow{4}{*}{4 m Caisson } & $V_{c s}$ & 0.980 \\
\cline { 2 - 3 } & $V_{c c}$ & 0.967 \\
\cline { 2 - 3 } & $V_{s s}$ & 0.961 \\
\hline \multirow{3}{*}{5 m Caisson } & $V_{c s}$ & 0.980 \\
\cline { 2 - 3 } & $V_{c c}$ & 0.967 \\
\cline { 2 - 3 } & $V_{s s}$ & 0.923 \\
\hline \multirow{3}{*}{6 m Caisson } & $V_{c s}$ & 0.982 \\
\cline { 2 - 3 } & $V_{c c}$ & 0.967 \\
\cline { 2 - 3 } & $V_{s s}$ & 0.970 \\
\hline
\end{tabular}

\subsubsection{Goodness of fit of a linear regression}

The coefficient of determination, denoted R2, was calculated to measured how the linear regression model fit the design results of material quantity, called as the goodness of fit.

The $\mathrm{R} 2$ has the interval between 0 and 1 . The larger value of R2 indicates the better results of the regression model to predict the dependent variable. The coefficient of determination R2 test results can be seen in Table 4. It can be seen that the $\mathrm{R} 2$ values for all regression equations exceed 0.9. It indicates that the proposed model can satisfactory in estimating the material quantity of bridge sub structure.

Table 4. The coefficient of determination test R2

\begin{tabular}{|c|c|c|c|}
\hline Structure & $\begin{array}{c}\text { Dependent } \\
\text { Variable }\end{array}$ & $\mathrm{R} 2$ & $\begin{array}{c}\text { Standart error } \\
\text { of estimate }\end{array}$ \\
\hline \multirow{3}{*}{ Abutment } & $V_{c}$ & 0.972 & 20.09 \\
\cline { 2 - 4 } & $V_{s}$ & 0.970 & 2398.46 \\
\hline \multirow{3}{*}{4 m caisson } & $V_{c s}$ & 0.961 & 13.62 \\
\cline { 2 - 4 } & $V_{c c}$ & 0.965 & 13.55 \\
\cline { 2 - 4 } & $V_{s s}$ & 0.921 & 876.68 \\
\hline \multirow{3}{*}{$5 \mathrm{~m}$ caisson } & $V_{c s}$ & 0.960 & 14.43 \\
\cline { 2 - 4 } & $V_{c c}$ & 0.935 & 17.99 \\
\cline { 2 - 4 } & $V_{S S}$ & 0.968 & 539.9 \\
\hline \multirow{3}{*}{$6 \mathrm{~m}$ caisson } & $V_{c s}$ & 0.964 & 15.57 \\
\cline { 2 - 4 } & $V_{c c}$ & 0.935 & 24.67 \\
\cline { 2 - 4 } & $V_{s s}$ & 0.941 & 1064.109 \\
\hline
\end{tabular}

\section{Conclusion}

This research proposed 11 equation models to estimate the concrete volume and reinforcing steel weight of abutment and caisson. Based on the results of statistical analysis, it can be seen that the coefficient of determination R2 for all proposed model exceed 0.9. It indicates that the proposed 
model can satisfactory estimate the material quantity of bridge sub structure. Based on multiple correlation test, it can be concluded that the concrete volume and reinforcing steel weight of abutment and caisson are strongly influenced by the span length and height of the abutment.

\section{References}

1. The National Standarization Agency of Indonesia, Standard of earthquake resistant design for bridges (SNI 2833:2008), Jakarta: BSN. (2008) [in Indonesian]

2. The National Standarization Agency of Indonesia, Bridges Loading Standard (SNI 1725:2016), Jakarta: BSN. (2016) [in Indonesian]

3. Fragkakis, N., Pantouvakis, J.P., Lambropoulos, S., (2010), A cost estimate method for bridge superstructures using regression analysis and bootstrap: organization, technology and management in construction, An International Journal, 2(2): 182191

4. Fragkakis, N., Marinelli, M., Lambropoulos, S., Preliminary Cost Estimation Model For Culvert, Procedia Engineering, 123, 153 - 161 (2015)

5. Fragkakis, N., Lambropoulos, S., Tsiambaos, G., Parametric Model for Conceptual Cost Estimationof Concrete Bridge Foundations, Journal of infrastructure systems, 17, 66-74 (2011)

6. Hollar, D., Rasdorf, W., Liu, Hummer, J., Arocho, I., Hsiang, S., Preliminary Engineering Cost Estimation Model for Bridge Projects, Journal of construction engineering and management, 139, 1259-1267 (2013)

7. Lowe, D. J., Emsley, M. W., Harding, A., Predicting Construction Cost Using Multiple Regression Techniques. New York: ASCE, Journal Of Construction Engineering And Management.

8. Muis, A. R., Preliminary Cost Estimation of Bridge Construction. Thesis. Bandung: Bandung Institute Of Technology (1995) [in Indonesian]

9. Sulistyani, H., Volume and Cost Estimation Model of Patching Work (Case Study of National Roads under Management of Local Service Unit in Yogyakarta Special District). (2014) [in Indonesian]

10. WIKA Beton, Standard Product Drawing. Bekasi: PT Wijaya Karya Beton. (2012) [in Indonesian] 